\title{
Factors Affecting Work Motivation (Empirical Study on Administrative Staff of Tarutung State College of Christian)
}

\author{
Samosir, Lustani \\ \{lustani_s@yahoo.co.id\} \\ Tarutung State College of Christian
}

\begin{abstract}
This article presents a summary of the results of study which aimed to determine the effect of work ability, religiosity, organizational justice, and work context on work motivation, with the hypothesis that there is a positive direct effect of work ability $\left(\mathrm{X}_{1}\right)$ on work motivation, there is a positive direct effect of religiosity $\left(\mathrm{X}_{2}\right)$ towards work motivation, there is a positive direct effect of organizational justice $\left(\mathrm{X}_{3}\right)$ on work motivation, and there is a positive direct effect of the work context $\left(\mathrm{X}_{4}\right)$ on work motivation (Y). The study was conducted with inferential quantitative approach. Population consisted of 63 employees of education staff which determined by stratified proportional random sampling in a number of 31 respondents.Data was processedby SPSS using the Path analysis formula. The results of the study concluded: 1) The contribution of work ability to work motivation is $17.30 \%$, with the path coefficient $(\rho y x 1)=0.416$, the value of sig. $0.012<0.05$, meaning that $\mathrm{Ho}$ is rejected, $\mathrm{Ha}$ is accepted. Religiosity contribution to work motivation is $17.47 \%$, with path coefficient ( Organizational justice contributes positively but is very small and not significant to work motivation, at $1.34 \%$, with path coefficient $(\rho y x 3)=0.116$, sig value. $0.608>0.05$ means that $\mathrm{Ho}$ is accepted, Ha is rejected. Contribution of work context to work motivation is $24.50 \%$ with path coefficient ( $\rho y x 4)=0.495$, sig value. $0.035<0.05$ thus Ho is rejected, $\mathrm{Ha}$ is accepted. The implication of the research results is, for improving work motivation of the staff, give the opportunity to employees to improve their ability to work with training in their respective fields of work, improve religiosity, and give training in understanding the context of each work. While the organizational justice factor $\left(\mathrm{X}_{3}\right)$ has a weak impactingtowards the respondents.
\end{abstract}

Keyword: Work Motivation, Job Ability, Religiosity, Organizational Justice and Job Context

\section{Introduction}

Educational staff (administrative staff) is one of the human resource groups that also influences the quality of universities by synergizing with educators (lecturers). In order to do work in the administration (administration), education staff need to get the attention of the leadership, and must be encouraged to do work so that they do not feel neglected, but feel needed, instead. Thus,this group will have high work motivation and be willing to do the whole set of work properly. Educational staff has the role of preparing all the needs of the learning process, for instance: attendance list, assessment list, learning facilities / media, and 
other academic administration that support the entire process that take place on campus. All activities must be documented, and some important things might also be published. Documentation and publication must be good, thereof, whenever it is needed the complete data is available, for example for assessment activities by the National Accreditation Board of Higher Education (BANPT) in the context of field assessment. All evidence of activities that have been carried out for approximately four years must be clearly shown. Therefore, the leader needs to examine the factors that motivate education staff so that they have high work motivation.

In this study examined several factors that influence the work motivation of administrative employees in STAKPN Tarutung as the dependent variable (Y), individual abilities as the first independent variable $\left(\mathrm{X}_{1}\right)$, Religionity $\left(\mathrm{X}_{2}\right)$, organizational justice (organizational Justice $\left(\mathrm{X}_{3}\right)$ and job context $\left(\mathrm{X}_{4}\right)$ as intervening variables. The results of this study are expected to provide input to the leadership elements in STAKPN Tarutung in a decision-making process that is able to increase employee motivation so that they are able to work optimally to achieve STAKPN Tarutung's vision and mission as a state asset in preparing Indonesia's human development resources.

\subsection{Work Motivation (Y)}

Bloisi, Cook, and Hunsaker Mullins, Jenifer and Gareth, Robbins, and Schermerhorns, suggest work motivation is a psychological boost that makes someone is able to work hard with more diligence in certain activities, compared to doing other activities. The work motivation regarding in this study is the power of encouragement that possessing by the administrative staff of STAKPN Tarutung which was assessed by questionnaires against the administrative employees of STAKPN Tarutung as respondents with indicators: 1) focused and directed at the objectives to be achieved, 2) intense or diligent and active and looking for various solutions to complete work, 3) quality means trying to complete the work with the correct procedures and results, and 4) the duration of work, meaning having the endurance and willing to increase work time to achieve the goal.

\subsection{Work Ability $\left(\mathrm{X}_{1}\right)$}

Individual work ability is the basic power to complete various jobs. Colquit, Lepine and Wesson, Robbins and Judge, Gibson, Blanchard, describe work ability as what is expected in the workplace, including knowledge, expertis, and the attitude in its application must be consistent and in accordance with the performance standards required in the work. The work ability that take in account in this study is the ability or ability possessed by STAKPN Tarutung administration employees to complete the work well which was assessed by questionnaire against STAKPN Tarutung employees as respondents with indicators: 1) work knowledge, 2) work skills and 3) work attitude.

\subsection{Religiosity $\left(\mathrm{X}_{2}\right)$}

Religiosity is interpreted as obedience to the teachings of the religion adopted. In the context of work, employees who are religious are identified as people who are diligent, responsible and obedient to the rules of the organization because they are obedient to God.According to Glock (in Tina Afiatin, Holdcroft, Barbara, there are five dimensions of religiosity, first, dimensions of belief. This dimension invites people to obey the prevailing 
work rules, because they obey God. Second, the dimensions of religious rituals that discuss the extent to which a person performs ritual obligations in his religion. In practice, every Christian must believe that work comes from God, is accountable to God, and thinks that doing a good job is worshiping God. Third, the dimensions of experience are feelings or experiences that have been experienced and felt, invites every Christian to be grateful, surrender to the power of God, fear of sinning at work because they feel they are always seen and watched by God. Fourth, the dimension of religious knowledge which reveals how well someone understands the teachings of his religion that are implemented on his performance. Fifth, the dimensions of social-religious behavior, for example, how often someone helps colleagues if needed. The five dimensions above are indicative of the variable religiosity in this study.

\subsection{Organizational Justice $\left(\mathrm{X}_{3}\right)$}

Organizational justice refers to the perception of subordinates about fair and unfair treatment by the leadership. The basic value of justice is human dignity so that the basic principle of justice is respect for the dignity and rights attached to it.

Colquitt, LePine, Wesson, Lind \& Tyler explain if individuals feel treated fairly, will tend to show higher performance and behavior according to organizational rules, whereas if perceptions of injustice are formed in the minds of subordinates, they will trying to regain justice by reducing the number of contributions, for example, starting to arrive late before resorting to more severe actions, such as being often absent, not innovative and creative which ultimately harms the organization.Organizational justice includes four dimensions. First, the dimensions of distributive justice reflect the perceived justice of the results of decision making, for example decisions about salary amounts, rewards, evaluations, promotions, and work assignments, are allocated based on clear and correct norms. Supposedly, more results given to workers contribute more. Second, procedural justice reflects the justice felt by the process of decision making. Third, interpersonal justice reflects the perceived justice of the treatment received, for example the way leaders treat subordinates, should be dignified, sincere, not vilify, criticize, berate, or humiliate in public.

\subsection{Job Context (Job Context) (X4)}

Mitchell, and Larson and Mullins, arguedWork context refers to the conditions under which work is done and how specific types of information about the context of the work are usually identified during the analysis of the work include the reporting relationship, supervision received, statutes, authority, personal contacts, working conditions, and the physical and mental demands of the workers.Taylor in the Robins, Mullins, to advise that for the effective work of the need to adopt some of the principles. First, develop the science to suit each element of work to replace old methods of work. Second, choose how to train, teach, and develop, do not choose his own work and train yourself. Third, sincerely work together with others to ensure that all work is done in accordance with principles that models are developed. Fourth, create a division of work and responsibility between management and workers. Management assumed that more weight, do not assign to the workers. The fourth principle above be context indicator variable job.

In this study the hypothesis was proposed: 1) there is a positive direct effect of work ability (X1) on work motivation, 2) there is a positive direct effect of religiosity (X2) on work motivation, 3) there is a positive direct effect of organizational justice (X3) on work motivation, and 4) there is a positive direct effect of the work context (X4) on work 
motivation (Y) with the following hypothetical model:

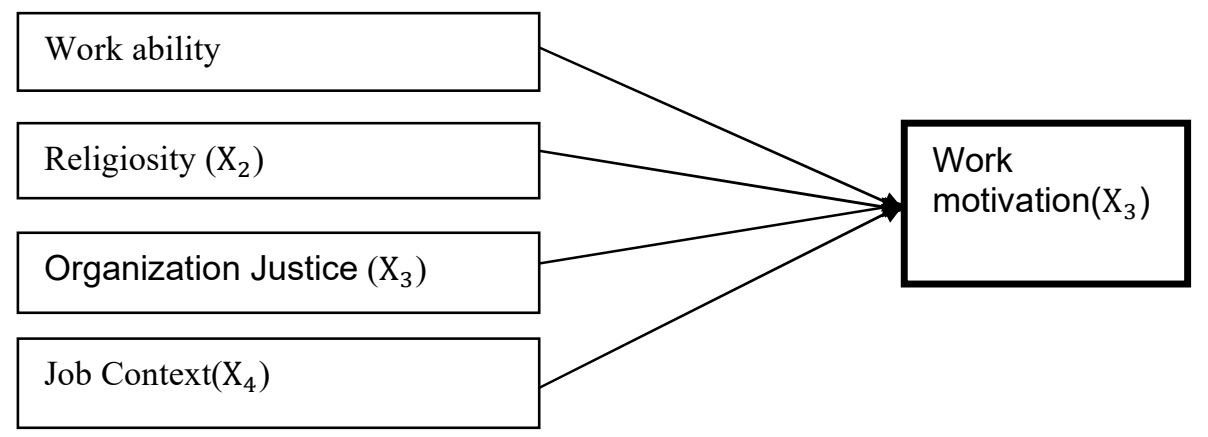

\section{Methodology}

The approach of this research is quantitative inferential, which is carried out in STAKPN Tarutung with a population of all education staff (administrative employees) totaling 63 people, the sample was determined by proportional random sampling (31 people). The research instrument for all variables was a closed questionnaire totaling 75 items which were compiled by the researchers themselves based on indicators. Data analysis includes descriptive and inferential statistical analysis. Hypothesis testing was carried out provisions: Ho: $\mathrm{p}_{\mathrm{yx}}=0$ and $\mathrm{H} 1: \mathrm{p}_{\mathrm{yx}}>0$ for all hypotheses

\section{Result and Discussion}

From the results of the data analysis, the following are summarized path coefficients and contribution of variables:

\begin{tabular}{llccc}
\hline No & \multicolumn{1}{c}{ The direct effect of } & path coefficient & $\mathbf{t}_{\text {count }}$ & Contribution \\
\hline 1 & Work ability (X1) to work motivation. (Y) & 0,416 & 0,012 & $17,30 \%$ \\
2 & Religiosity (X2) to work motivation (Y) & 0,418 & 0,012 & $17,47 \%$ \\
3 & Organizational Justice (X3) to work motivation (Y) & 0,116 & 0,608 & $1,34 \%$ \\
4 & Job context (X4) to work motivation (Y) & 0,495 & 0,035 & $24,50 \%$ \\
\hline
\end{tabular}

Based on data analysis, the factors that influence the work motivation of educational staff in Tarutung State College of Christian are work ability, religiosity and work context. Whereas organizational justice factors are not influential. This indicates that education staff perform routine tasks in the office only influenced by self and work factors, while management factors have not yet become a concern.

The findings of the study indicate that the fourth hypothesis is accepted as truth, thus the work context variable has a direct positive effect on the motivation of work. Therefore the work context is one of the important factors for increasing work motivation. 


\section{Conclusion}

1. The contribution of work ability to work motivation is $17.30 \%$, with path coefficient $\left(\rho_{\mathrm{yx}} 1\right)=0.416$, sig value. $0.012<0.05$, meaning that Ho is rejected, Ha is accepted

2. Religiosity contribution to work motivation is $17.47 \%$, with path coefficient $\left(\rho_{\mathrm{yx}} 2\right)=$ 0.418 , sig value. $0.012<0.05$ means that Ho is rejected, Ha is accepted

3. Organizational justice contributes positively but is very small and not significant to work motivation, at $1.34 \%$, with path coefficient $\left(\rho_{\mathrm{yx}} 3\right)=0.116$, sig value. $0.608>0.05$ means that Ho is accepted, Ha is rejected.

4. Contribution of work context to work motivation is $24.50 \%$ with path coefficient $\left(\rho_{\mathrm{yx}} 4\right)=$ 0.495 , sig value. $0.035<0.05$ thus Ho is rejected, Ha is accepted.

\section{Implications}

The research implications are: 1) To increase work motivation, then give opportunities to employees to improve their work ability. 2) To increase work motivation, then give time and direction to improve employee religiosity. 3) To increase work motivation, then improve the work context.

\section{References}

[1] Bloisi, Wendy, Cook, W. Curtis dan Phillip L. Hunsaker, Management And Organizational Behavior. New York: McGrow-Hill Education, p.172 (2003)

[2] Colquitt, LaPine, Wesson, Organizational Behavior: Improving Performance and commitment in the workplace. New York: McGrow-Hill, p.340 (2009).

[3] Gibson L., James, Donnelly, Ivancevich and Konopaske.Organizations; Twelfth Edition.New York: McGraw-Hill, p.215 (2006)

[4] Hersey, Paul, Blanchard H. Kenneth and JhonsonE.Dewey, Management of Organizational Behavior, leading Human Resources. New Jersey: Pearson Prentice-Hall, p.185 (2008)

[5] Jones, M. Jennifer dan Jones, R. Gareth.Understanding and Managing Organizational Behavior .New York Person Prentice Hall, p.175 (2005).

[6] Laurie J. Mullins. Management And Organizational Behavior;Third Edition. (Singapore: Pitman Publishing, 2005), p.959.

[7] Lind, E.A. \& Tyler, T.R.The Social Psychology of Procedural Justice. N.Y.: Plenum. Translated into Japanese. Tokyo: Tuttle-Mori Publishing, 1988)p.174

[8] Schermerhorn, R.Jhon, at.all. Organizational Behavior.New York: John Wiley \& Sons Inc.,p.130 (2011)

[9] (September 2006).https://en.wikipedia.org/wiki/Religiosity "What is Religiosity?". Catholic Education: A Journal of Inquiry and Practice. 10 (1): 89-103

[10] Stephen Robin danTimothy A.Judge.Organizational Behavior; 13 $3^{\text {th }}$ Edition. New Jersey; Prentice-Hall,p.209,

[11] 2009)

[12] andTimothy A.Judge. Organizational Behavior; $14^{\text {th }}$ Edition. New Jersey; PrenticeHall,p.57 (2011).

[13] Tina Afiatin ReligiusitasRemaja; StuditentangKehidupanBeragama di Daerah Istimewa Yogyakarta, JurnalPsikologiUmum,UGM, No.1,55 (1998)

[14] Terence R Mitchell, and James R Larson, Jr., People in Organizations, An Introduction to Organization Behaviour; Third Edition (New York: McGraw-Hill Book Company, p.226 (2001) 